\title{
Oceanicola nitratireducens sp. nov., a marine alphaproteobacterium isolated from the South China Sea
}

\author{
Qiang Zheng, ${ }^{1}$ Chuang Chen, ${ }^{1}$ Ya-Nan Wang ${ }^{1,2}$ and Nianzhi Jiao ${ }^{1}$ \\ ${ }^{1}$ State Key Laboratory of Marine Environmental Science, Xiamen University, Xiamen 361005, \\ PR China \\ ${ }^{2}$ Key Laboratory of Microbial Engineering at the Institute of Biology, Henan Academy of Sciences, \\ Zhengzhou 450008, PR China
}

Correspondence

Nianzhi Jiao

jiao@xmu.edu.cn
The genus Oceanicola, which belongs to the order Rhodobacterales of the class Alphaproteobacteria, was first proposed by Cho \& Giovannoni (2004). Currently, the genus includes five species, Oceanicola granulosus (the type species), Oceanicola batsensis, Oceanicola nanhaiensis, Oceanicola marinus and Oceanicola pacificus, which are Gram-negative, non-motile, poly- $\beta$-hydroxybutyrate (PHB)-accumulating and contain large amounts of unsaturated cellular fatty acids. O. granulosus strains HTCC2516 ${ }^{\mathrm{T}}$ and HTCC2523 and O. batsensis HTCC $2597^{\mathrm{T}}$ were isolated from the Bermuda Atlantic Time-series Study (BATS) site by means of a high-throughput culturing method based on dilution-toextinction in an oligotrophic seawater-based medium (Cho \& Giovannoni, 2003). O. nanhaiensis SS011B1-20 ${ }^{\mathrm{T}}$ was isolated from sediment samples from the South China Sea (Gu et al., 2007). O. marinus was obtained from seawater collected off the coast of Taiwan (Lin et al., 2007). O. pacificus was isolated from a deep-sea pyrene-degrading consortium (Yuan et al., 2009). All strains of this genus were isolated from the ocean. JLT1210 ${ }^{\mathrm{T}}$ was isolated from the Beibu Gulf in the South China Sea and was subjected to taxonomic investigation. Polyphasic taxonomic analyses indicated that this marine isolate represents a novel species of the genus Oceanicola.

Abbreviation: $\mathrm{PHB}$, poly- $\beta$-hydroxybutyrate; $\mathrm{RO}$, rich organic [medium]. The GenBank/EMBL/DDBJ accession number for the 16S rRNA gene sequence of strain JLT1210 ${ }^{\top}$ is EU581832.
During our surveys of the biodiversity of bacteria in the South China Sea during voyage no. 908 on the ship Dongfanghong 2 in July 2006, strain JLT $1210^{\mathrm{T}}$ was obtained after direct plating of seawater dilutions. It was incubated in a rich organic (RO) medium (Yurkov et al., 1999) at room temperature $\left(28{ }^{\circ} \mathrm{C}\right)$ for 10 days. RO medium contained the following $\left(\mathrm{g} \mathrm{l}^{-1}\right)$ : yeast extract, 1.0; Bacto Peptone, 1.0; sodium acetate, $1.0 ; \mathrm{KCl}, 0.3 ; \mathrm{MgSO}_{4} .7 \mathrm{H}_{2} \mathrm{O}$, $0.5 ; \mathrm{CaCl}_{2} .2 \mathrm{H}_{2} \mathrm{O}, 0.05 ; \mathrm{NH}_{4} \mathrm{Cl}, 0.3 ; \mathrm{K}_{2} \mathrm{HPO}_{4}, 0.3$; and $\mathrm{NaCl}, 20.0$. This medium was supplemented with a mixture of vitamins and trace element solution.

Cell morphology was examined by transmission electron microscopy (JEM $2100 \mathrm{HC}$ ). The Gram reaction was determined on cells grown on $\mathrm{RO}$ at $25{ }^{\circ} \mathrm{C}$ for $24 \mathrm{~h}$ according to the method described by Gerhardt et al. (1994). Colonies were pale yellow, $0.5-3.0 \mathrm{~mm}$ in diameter, uniformly circular, convex and opaque after growth on marine agar RO at $28{ }^{\circ} \mathrm{C}$ for 3 days. Cells stained Gramnegative and were short rods, $0.7-2.1 \mu \mathrm{m}$ long and $0.4-$ $1.1 \mu \mathrm{m}$ wide, with polar or subpolar flagella, dividing by binary fission (Fig. 1).

The salt requirement for growth of strain JLT1210 ${ }^{\mathrm{T}}$ was tested by growth on RO medium with final $\mathrm{NaCl}$ concentrations of $0,2,5,10,15,20,25$ and $30 \%(\mathrm{w} / \mathrm{v})$ $\left(\mathrm{pH} 7.8\right.$ at $\left.28{ }^{\circ} \mathrm{C}\right)$. The $\mathrm{pH}$ and temperature requirements for growth were determined by adjusting the final $\mathrm{pH}$ of RO medium to $\mathrm{pH} 0,2,4,6,7,8,10,12$ and 14 with $\mathrm{HCl}$ and $\mathrm{NaOH}\left(2 \% \mathrm{NaCl}, 28{ }^{\circ} \mathrm{C}\right)$, and by incubation at $4-$ $45{ }^{\circ} \mathrm{C}\left(4,10,15,25,28,37\right.$ and $\left.45{ }^{\circ} \mathrm{C}\right)(2 \% \mathrm{NaCl}, \mathrm{pH} 7.8)$, 

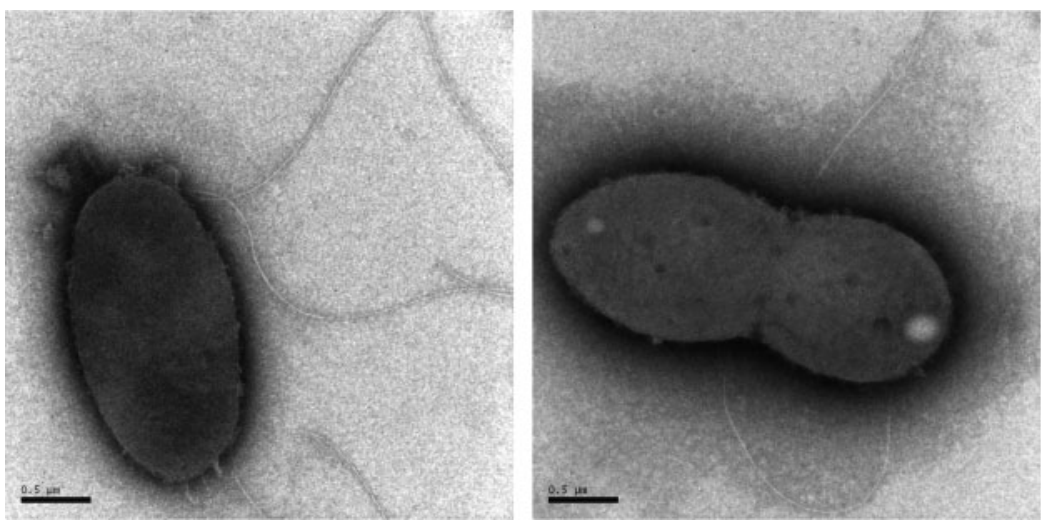

Fig. 1. Electron micrographs of negatively stained cells of strain $\mathrm{JLT} 1210^{\top}$ observed by transmission electron microscopy. Bars, $0.5 \mu \mathrm{m}$

respectively. The temperature range for growth of strain JLT $1210^{\mathrm{T}}$ was $10-45{ }^{\circ} \mathrm{C}$ (optimum $28{ }^{\circ} \mathrm{C}$ ), the $\mathrm{pH}$ range for growth was $\mathrm{pH} 7.0-9.5$ (optimum 7.8-8.5) and the $\mathrm{NaCl}$ concentration range for growth was $0.5-7.0 \%(\mathrm{w} / \mathrm{v})$ (optimum 1.5-3.0\%).

Oxidase activity of strain JLT $1210^{\mathrm{T}}$ was tested according to the method of Smibert \& Krieg (1994) and catalase activity was determined by using $3 \%(\mathrm{v} / \mathrm{v})$ hydrogen peroxide solution (Dong \& Cai, 2001). Nitrite and nitrate reduction were tested in $\mathrm{RO}$ medium by growing the strain in the presence of $\mathrm{NO}_{2}^{-}$and $\mathrm{NO}_{3}^{-}$, respectively (Dong \& Cai, 2001). Denitrification was tested by growing the strain anaerobically in the presence of $\mathrm{NO}_{3}^{-}$(Zumft, 1992). Hydrolysis of starch, gelatin and Tween 80 , and urease activity were determined as described by Dong \& Cai (2001). $\mathrm{H}_{2} \mathrm{~S}$ production was tested in $\mathrm{RO}$ medium supplemented with $0.01 \% \mathrm{~L}$-cysteine, the indicator being a strip of paper impregnated with lead acetate placed in the neck of the tube (Clarke, 1953; Mata et al., 2002). Methyl red and Voges-Proskauer tests were performed by using methyl red and Barritt's reagent (Barritt, 1936; Mata et al., 2002). Accumulation of PHB was determined by the Sudan Black staining method (Smibert \& Krieg, 1994). Growth on sole carbon and nitrogen sources was examined according to the procedures described by Williams et al. (1983) on $\mathrm{RO}$ medium without organic compounds at $28{ }^{\circ} \mathrm{C}$ for 7 14 days.

The isolate was positive for oxidase and catalase activities. Biochemical tests were positive for aerobic nitrate reduction, and $\mathrm{PHB}$ and $\mathrm{H}_{2} \mathrm{~S}$ production. Gelatin, starch, Tween 80 and casein hydrolysis, indole production, aerobic nitrite reduction, anaerobic nitrate reduction, methyl red and Voges-Proskauer tests, and urease activity were negative.

The strain utilized a wide range of substrates, including hexoses, oligosaccharides, organic acids and amino acids, as sole carbon sources. Antimicrobial susceptibility tests were performed by using the disc-diffusion plate (KirbyBauer) method according to Fraser \& Jorgensen (1997) and Andrews (2008), and with the antimicrobial compounds suggested by Mata et al. (2002).
Table 1. Fatty acid composition (\%) of strain $\mathrm{JLT} 1210^{\top}$ and type strains of related Oceanicola species

Taxa: 1, JLT1210 ${ }^{\mathrm{T}}$; 2, Oceanicola nanhaiensis ( $\mathrm{Gu}$ et al., 2007); 3, Oceanicola granulosus (Cho \& Giovannoni, 2004); 4, Oceanicola batsensis (Cho \& Giovannoni, 2004); 5, Oceanicola marinus (Lin et al., 2007); 6, Oceanicola pacificus (Yuan et al., 2009).

\begin{tabular}{|c|c|c|c|c|c|c|}
\hline Fatty acid & 1 & 2 & 3 & 4 & 5 & 6 \\
\hline $10: 0$ & - & 0.2 & 0.1 & - & - & - \\
\hline $10: 03-\mathrm{OH}$ & 0.1 & 1.0 & 1.5 & 0.4 & 0.1 & - \\
\hline $11: 03-\mathrm{OH}$ & - & - & - & - & - & 0.4 \\
\hline $12: 0$ & 2.4 & 0.1 & - & 2.0 & - & - \\
\hline $12: 1 \omega 11 c$ & - & - & - & 4.9 & - & - \\
\hline $12: 02-\mathrm{OH}$ & - & - & - & - & - & 0.4 \\
\hline $12: 03-\mathrm{OH}$ & 1.8 & - & 1.6 & - & 2.1 & - \\
\hline $12: 13-\mathrm{OH}$ & - & - & - & - & - & 1.6 \\
\hline $14: 0$ & 3.8 & 0.3 & - & 1. 5 & 0.2 & 0.3 \\
\hline $14: 03-\mathrm{OH}$ & - & 0.9 & - & - & - & - \\
\hline iso- $15: 0$ & 0.8 & - & - & - & - & - \\
\hline anteiso- $15: 0$ & 0.8 & - & - & - & - & - \\
\hline $15: 0$ & 1.6 & - & - & 0.9 & - & 1.0 \\
\hline iso- $16: 0$ & 0.8 & - & - & - & - & - \\
\hline $16: 0$ & 16.2 & 7.0 & 11.9 & 15.0 & 14.7 & 3.8 \\
\hline anteiso- $17: 0$ & 0.1 & - & 0.2 & - & - & - \\
\hline cyclo $17: 0$ & - & - & 0.2 & - & - & - \\
\hline $17: 1 \omega 8 c$ & 1.7 & 0.4 & 0.3 & - & - & 1.6 \\
\hline $17: 1 \omega 6 c$ & 0.6 & - & - & - & - & 1.3 \\
\hline $17: 0$ & 1.1 & 0.4 & 0.4 & 1. 5 & - & 6.6 \\
\hline $18: 1 \omega 7 c$ & 25.7 & 81.2 & 62.8 & 31.0 & 49.1 & 32.1 \\
\hline $18: 0$ & 0.9 & 1.3 & 0.9 & 2.4 & 1.0 & 7.3 \\
\hline Methyl 18: 1 & - & 4.3 & 8.1 & - & 6.6 & 19.5 \\
\hline cyclo 19: 1 & - & 1.1 & 10.8 & 40.4 & 24.6 & 20.9 \\
\hline $20: 2 \omega 6,9 c$ & - & - & - & - & 0.2 & 0.4 \\
\hline \multicolumn{7}{|c|}{ Summed feature:* } \\
\hline 3 & 40.5 & 1.8 & 1.2 & - & 1.0 & 0.7 \\
\hline 7 & 1.1 & - & - & - & 0.4 & - \\
\hline Total & 100 & 100 & 100 & 100 & 100 & 99.9 \\
\hline
\end{tabular}

${ }^{*}$ Summed feature 3 comprises iso-15:0 2-OH and/or $16: 1 \omega 7 c$; summed feature 7 comprises 19:0 cyclo $\omega 10 c$ and/or $19: 1 \omega 6 c$. 
The chemotaxonomic study of strain JLT $1210^{\mathrm{T}}$ included analysis of its cellular fatty acids. Cellular fatty acid analysis was carried out as described by Komagata \& Suzuki (1987). Isoprenoid quinones were analysed as described by Hiraishi et al. (1998) using a UPLC-Q-TOF-MS spectrometer and the electrospray ionization method (Romano et al., 2006). The predominant fatty acid was summed feature 3 (iso- $\mathrm{C}_{15: 0}$ 2-OH and/or $\left.\mathrm{C}_{16: 1} \omega 7 c, 40.5 \%\right)$; significant amounts of $\mathrm{C}_{18: 1} \omega 7 c(25.7 \%), \mathrm{C}_{16: 0}(16.2 \%), \mathrm{C}_{14: 0}(3.8 \%), \mathrm{C}_{12: 0}$ $(2.4 \%), \mathrm{C}_{12: 0} 3-\mathrm{OH}(1.8 \%), \mathrm{C}_{17: 1} \omega 8 c(1.7 \%), \mathrm{C}_{15: 0}(1.6 \%)$ and $\mathrm{C}_{17: 0}(1.1 \%)$ were also present. Fatty acid profiles of members of the genus Oceanicola are listed in Table 1.

Genomic DNA was extracted using the method of Marmur (1961) from cells grown in RO medium for 2 days at $28{ }^{\circ} \mathrm{C}$, washed and resuspended in TE buffer [10 mM Tris$\mathrm{HCl}$ ( $\mathrm{pH}$ 7.5), 1 mM EDTA ( $\mathrm{pH}$ 8.0)]. Purity was assessed using $A_{280} / A_{260}$ and $A_{230} / A_{260}$ ratios (Johnson, 1994). Phylogenetic analyses based on 16S rRNA gene sequences were performed as described by Lin et al. (2007). The $16 \mathrm{~S}$ rRNA gene was amplified with universal bacterial primers corresponding to Escherichia coli positions 8F (5'-AGAGTTTGATCCTGGCTCAG) and 1492R (5'-GGTTACCTTGTTACGACTT) (Embley, 1991). The 16S rRNA gene sequence of strain JLT $1210^{\mathrm{T}}$ was compared with those available in GenBank using the BLAST program (NCBI) to determine the approximate phylogenetic affiliation. The 16S rRNA gene sequence of strain JLT1210 ${ }^{\mathrm{T}}$ was aligned with those of related Oceanicola species and phylogenetic trees were constructed using the neighbour-joining and maximum-parsimony methods of the MEGA software (Kumar et al., 2004; Fig. 2). Nearly complete 16S rRNA gene sequences (1386 bp) were determined for strain JLT1210 ${ }^{\mathrm{T}}$ and used for phylogenetic analyses. The closest neighbours were $O$. nanhaiensis SS011B1-20 ${ }^{\mathrm{T}}(96.5 \%$ similarity), O. batsensis HTCC $2597^{\mathrm{T}}(96.4 \%)$ and $O$. granulosus HTCC2516 ${ }^{\mathrm{T}}$ (93.2\%).

The genomic DNA G + C content of strain JLT1210 ${ }^{\mathrm{T}}$ was estimated from the midpoint value $\left(T_{\mathrm{m}}\right)$ of the thermal denaturation profile, as described by Mandel et al. (1970). The DNA G + C content of strain JLT1210 ${ }^{\mathrm{T}}$ was $72.8 \mathrm{~mol} \%$ and the predominant respiratory ubiquinone was Q-10.

\section{Description of Oceanicola nitratireducens sp. nov.}

Oceanicola nitratireducens (ni.tra.ti.re.du'cens. N.L. n. nitras -atis nitrate; L. part. adj. reducens leading back, bringing back and in chemistry converting to a different

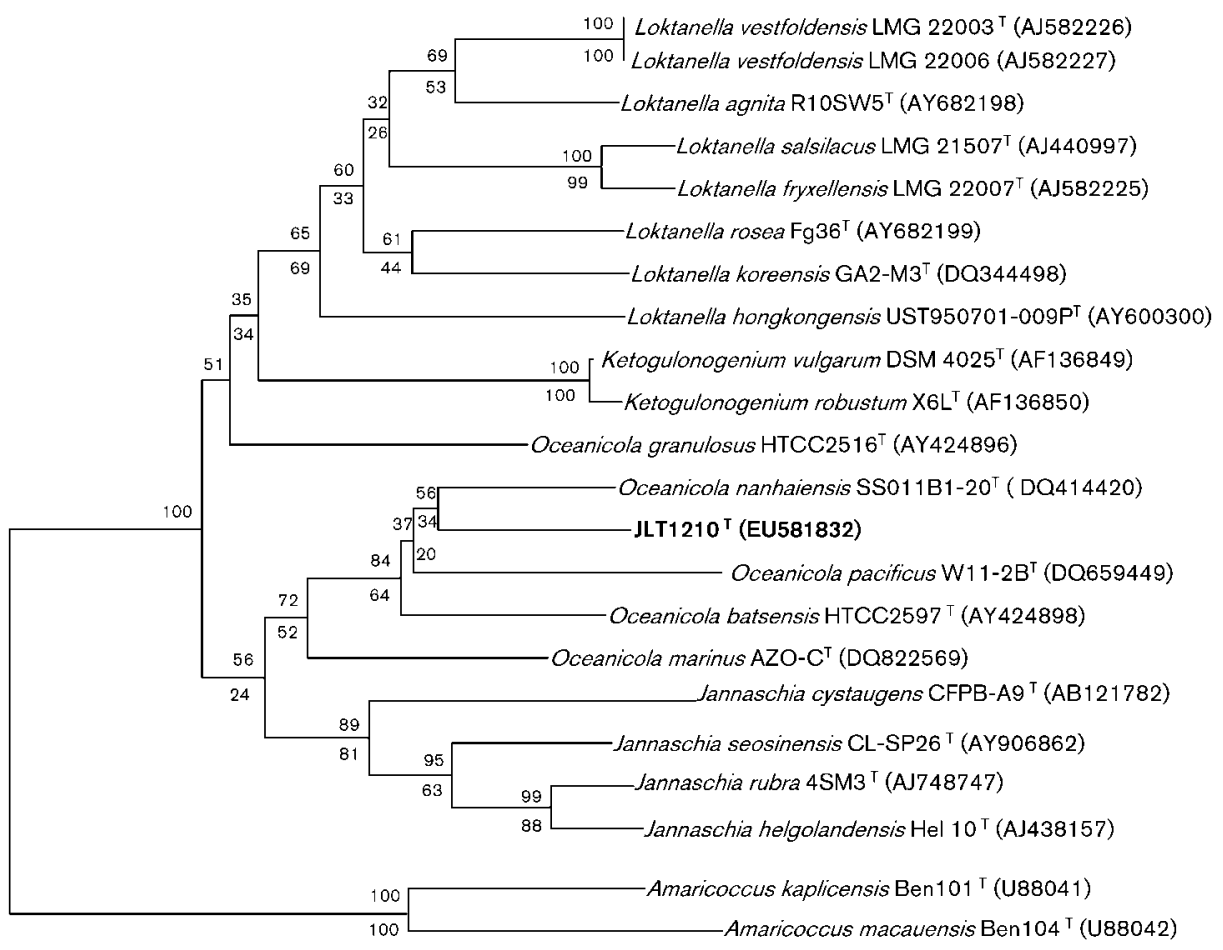

0.01

Fig. 2. Neighbour-joining phylogenetic tree for strain $J L T 1210^{\top}$ based on $16 \mathrm{~S}$ rRNA gene sequence analysis. Bootstrap percentages from both neighbour-joining (values above nodes) and maximum-parsimony (values below nodes) are shown. Bar, 0.01 substitutions per nucleotide position. 
Table 2. Differential characteristics of Oceanicola nitratireducens sp. nov. strain JLT1210 ${ }^{\top}$ and type strains of related species of the genus Oceanicola

Taxa: 1, JLT1210 ${ }^{\mathrm{T}}$; 2, Oceanicola nanhaiensis (Gu et al., 2007); 3, Oceanicola granulosus (Cho \& Giovannoni, 2004); 4, Oceanicola batsensis (Cho \& Giovannoni, 2004); 5, Oceanicola marinus (Lin et al., 2007); 6, Oceanicola pacificus (Yuan et al., 2009). +, Positive; -, negative; w, weak reaction; ND, not determined.

\begin{tabular}{|c|c|c|c|c|c|c|}
\hline Characteristic & 1 & 2 & 3 & 4 & 5 & 6 \\
\hline $\mathrm{G}+\mathrm{C}$ content $(\mathrm{mol} \%)$ & 72.8 & 64.7 & 67.3 & 71.5 & 70.9 & 64.6 \\
\hline Catalase & + & $\mathrm{w}$ & - & + & + & + \\
\hline Urease & - & - & - & + & + & - \\
\hline Tween 80 & - & + & + & - & - & - \\
\hline Nitrate reduction & + & W & - & - & - & - \\
\hline Temperature range for growth $\left({ }^{\circ} \mathrm{C}\right)$ & $10-37$ & $10-37$ & $4-40$ & $4-40$ & $4-42$ & $10-41$ \\
\hline $\mathrm{NaCl}$ range for growth $(\%, \mathrm{w} / \mathrm{v})$ & $0.5-7.0$ & $0-10$ & $0.25-10.0$ & $0.75-10.0$ & $2-8$ & $0.5-10.0$ \\
\hline $\mathrm{pH}$ range for growth & $7.0-9.5$ & $6.0-9.5$ & $5.5-9.5$ & 6-9 & $6-9$ & $6.5-11.0$ \\
\hline \multicolumn{7}{|l|}{ Susceptibility to: } \\
\hline Gentamicin & + & + & - & + & - & + \\
\hline Chloramphenicol & - & + & + & - & - & + \\
\hline Streptomycin & + & + & - & + & - & + \\
\hline Erythromycin & + & - & + & + & - & + \\
\hline \multicolumn{7}{|l|}{ Utilization of: } \\
\hline D-Malonic acid & $\mathrm{w}$ & - & - & + & - & - \\
\hline Lactic acid & - & - & $\mathrm{w}$ & + & ND & + \\
\hline Ethanol & + & + & - & - & $\mathrm{ND}$ & $\mathrm{ND}$ \\
\hline D-Sorbitol & $\mathrm{w}$ & + & - & - & - & - \\
\hline D-Mannitol & + & + & - & + & + & - \\
\hline D-Fructose & + & + & - & - & + & - \\
\hline Cellobiose & + & + & + & - & + & - \\
\hline Trehalose dihydrate & + & - & + & - & + & - \\
\hline Maltose & + & - & + & + & + & - \\
\hline D-Glucose & + & + & + & - & + & - \\
\hline D-Galactose & + & $\mathrm{ND}$ & + & + & + & $\mathrm{ND}$ \\
\hline Sucrose & + & + & + & - & + & - \\
\hline D-Xylose & $\mathrm{w}$ & - & - & - & + & ND \\
\hline L-Alanine & + & - & + & - & + & $\mathrm{w}$ \\
\hline L-Glycine & $\mathrm{w}$ & - & - & + & ND & $\mathrm{w}$ \\
\hline
\end{tabular}

oxidation state; N.L. part adj. nitratireducens reducing nitrate).

Cells are Gram-negative, non-motile, short rods with polar or subpolar flagella. Small (about $0.5-3.0 \mathrm{~mm}$ ) straw yellowish colonies are produced on $\mathrm{RO}$ after incubation at $28{ }^{\circ} \mathrm{C}$ for $3-5$ days. Colonies are smooth, convex and opaque. Growth occurs at $10-37{ }^{\circ} \mathrm{C}$, at $\mathrm{pH} 7.0-9.5$ and in $0.5-7.0 \% \mathrm{NaCl}$; optimum growth occurs at $28{ }^{\circ} \mathrm{C}$, at $\mathrm{pH} 7.8-8.5$ and in $1.5-3.0 \% \mathrm{NaCl}$. Positive for oxidase, catalase and nitrate reduction. Negative for hydrolysis of gelatin, starch, Tween 80 and casein, aerobic nitrite reduction, anaerobic nitrate reduction, methyl red and Voges-Proskauer tests, and indole production. The utilization of various substrates as sole carbon sources, antimicrobial susceptibility and other differentiating characteristics are listed in Table 2. The following substrates are utilized: maltose, sucrose, D-fructose, D-galactose, dextrin, trehalose dihydrate, cellobiose, citric acid, sodium Dgluconate, glycerol, mannitol, L-(-)-malic acid, acetic acid, ethanol, L-threonine, L-alanine, L-glycine and Larginine. Sensitive to ciprofloxacin, cephalothin, tetracycline, gentamicin, chloramphenicol and cefotaxime. The predominant fatty acid is summed feature 3 (iso- $\mathrm{C}_{15: 0} 2$ $\mathrm{OH}$ and/or $\mathrm{C}_{16: 1} \omega 7 c$ ); significant amounts of $\mathrm{C}_{18: 1} \omega 7 c$, $\mathrm{C}_{16: 0}, \mathrm{C}_{14: 0}, \mathrm{C}_{12: 0}, \mathrm{C}_{12: 0} 3-\mathrm{OH}, \mathrm{C}_{17: 1} \omega 8 c, \mathrm{C}_{15: 0}$ and $\mathrm{C}_{17: 0}$ are also present. The predominant respiratory ubiquinone is Q-10.

The type strain is $\mathrm{JLT} 1210^{\mathrm{T}}\left(=\mathrm{LMG} 24663^{\mathrm{T}}=\mathrm{CGMCC}\right.$ $1.7292^{\mathrm{T}}$ ), isolated from surface water of the Beibu Gulf in the South China Sea. The DNA G $+\mathrm{C}$ content of the type strain is $72.8 \mathrm{~mol} \%$ ( $T_{\mathrm{m}}$ method).

\section{Acknowledgements}

The authors would like to thank Professor Shuang-Jiang Liu, Institute of Microbiology, Chinese Academy of Science and China General Microbiological Culture Collection Center, for valuable help. This work was supported by the MOST project (2007CB815900), the NSFC projects (40632013), the SOA project (200805068), the 
National Infrastructure of Natural Resources for Science and Technology Program of China (2005DKA21209), the COMRA project (DYXM-115-02-4-3) and the Technical Innovation Project of Ministry of Education of China (704029).

\section{References}

Andrews, J. M. (2008). BSAC standardized disc susceptibility testing method (Version 7). J Antimicrob Chemother 62, 256-278.

Barritt, M. M. (1936). The intensification of the Voges-Proskauer reaction by the addition of $\alpha$-naphthol. J Pathol Bacteriol 42, 441-445.

Cho, J.-C. \& Giovannoni, S. J. (2003). Parvularcula bermudensis gen. nov., sp. nov., a marina bacterium that forms a deep branch in the $\alpha$ Proteobacteria. Int J Syst Evol Microbiol 53, 1031-1036.

Cho, J.-C. \& Giovannoni, S. J. (2004). Oceanicola granulosus gen. nov., sp. nov. and Oceanicola batsensis sp. nov., poly- $\beta$-hydroxybutyrateproducing marine bacteria in the order 'Rhodobacterales'. Int J Syst Evol Microbiol 54, 1129-1136.

Clarke, P. H. (1953). Hydrogen sulphide production by bacteria. J Gen Microbiol 8, 397-407.

Dong, X.-Z. \& Cai, M.-Y. (editors) (2001). Determination of biochemical properties. In Manual for the Systematic Identification of General Bacteria, pp. 370-398. Beijing: Science Press (in Chinese).

Embley, T. M. (1991). The linear PCR reaction: a simple and robust method for sequencing amplified rRNA genes. Lett Appl Microbiol 13, 171-174

Fraser, S. L. \& Jorgensen, J. H. (1997). Reappraisal of the antimicrobial susceptibilities of Chryseobacterium and Flavobacterium species and methods for reliable susceptibility testing. Antimicrob Agents Chemother 41, 2738-2741.

Gerhardt, P., Murray, R. G. E., Wood, W. A. \& Krieg, N. R. (editors) (1994). Methods for General and Molecular Bacteriology. Washington, DC: American Society for Microbiology.

Gu, J., Guo, B., Wang, Y.-N., Yu, S.-L., Inamori, R., Qu, R., Ye, Y.-G. \& $\mathrm{Wu}, \mathrm{X}$.-L. (2007). Oceanicola nanhaiensis sp. nov., isolated from sediments of the South China Sea. Int J Syst Evol Microbiol 57, 157-160.

Hiraishi, A., Ueda, Y. \& Ishihara, J. (1998). Quinone profiling of bacterial communities in natural and synthetic sewage activated sludge for enhanced phosphate removal. Appl Environ Microbiol 64, 992-998.

Johnson, J. L. (1994). Similarity analysis of DNAs. In Methods for General and Molecular Bacteriology, pp. 655-682. Edited by P. Gerhardt, R. G. E. Murray, W. A. Wood \& N. R. Krieg. Washington, DC: American Society for Microbiology.
Komagata, K. \& Suzuki, K. (1987). Lipid and cell-wall analysis in bacterial systematics. Methods Microbiol 19, 161-207.

Kumar, S., Tamura, K. \& Nei, M. (2004). MEGA3: integrated software for Molecular Evolutionary Genetics Analysis and sequence alignment. Brief Bioinform 5, 150-163.

Lin, K.-Y., Sheu, S.-Y., Chang, P.-S., Cho, J.-C. \& Chen, W.-M. (2007). Oceanicola marinus sp. nov., a marine alphaproteobacterium isolated from seawater collected off Taiwan. Int J Syst Evol Microbiol 57, 16251629.

Mandel, M., Igambi, L., Bergendahl, J., Dodson, M. L. \& Scheltgen, E. (1970). Correlation of melting temperature and cesium chloride buoyant density of bacterial deoxyribonucleic acid. J Bacteriol 101, 333-338.

Marmur, J. (1961). A procedure for the isolation of deoxyribonucleic acid from microorganisms. J Mol Biol 3, 208-218.

Mata, J. A., Martínez-Cánovas, J., Quesada, E. \& Béjar, V. (2002). A detailed phenotypic characterisation of the type strains of Halomonas species. Syst Appl Microbiol 25, 360-375.

Romano, I., Lama, L., Nicolaus, B., Poli, A., Gambacorta, A. \& Giordano, A. (2006). Halomonas alkaliphila sp. nov., a novel halotolerant alkaliphilic bacterium isolated from a salt pool in Campania (Italy). J Gen Appl Microbiol 52, 339-348.

Smibert, R. M. \& Krieg, N. R. (1994). Phenotypic characterization. In Methods for General and Molecular Bacteriology, pp. 607-654. Edited by P. Gerhardt, R. G. E. Murray, W. A. Wood \& N. R. Krieg. Washington, DC: American Society for Microbiology.

Williams, S. T., Goodfellow, M., Alderson, G., Wellington, E. M. H., Sneath, P. H. A. \& Sackin, M. J. (1983). Numerical classification of Streptomyces and related genera. J Gen Microbiol 129, 1743-1813.

Yuan, J., Lai, Q., Wang, B., Sun, F., Liu, X., Du, Y., Li, G., Gu, L., Zheng, T. \& Shao, Z. (2009). Oceanicola pacificus sp. nov., isolated from a deepsea pyrene-degrading consortium. Int J Syst Evol Microbiol 59, 1158 1161.

Yurkov, V. V., Krieger, S., Stackebrandt, E. \& Beatty, J. T. (1999). Citromicrobium bathyomarinum, a novel aerobic bacterium isolated from deep-sea hydrothermal vent plume waters that contains photosynthetic pigment-protein complexes. J Bacteriol 181, 45174525.

Zumft, W. G. (1992). The denitrifying bacteria. In The Prokaryotes. A Handbook on the Biology of Bacteria: Ecophysiology, Isolation, Identification, Application, pp. 554-582. Edited by A. Balows, H. G. Trüper, M. Dworkin, W. Harder \& K. H. Schleifer. New York: Springer. 